Jurnal Akuntansi dan Keuangan Volume V/1/Februari 2020

ISSN (Online) : 2503-1635, ISSN (Print): 2088-4656

\title{
Evaluasi Penerapan Sistem Pengendalian Intern Pemerintah Dalam Meningkatkan Penerimaan Pajak Daerah Pada Badan Pengelola Pajak dan Retribusi Daerah Kabupaten Kolaka
}

\author{
Oleh \\ Satira Yusuf ${ }^{1}$, Wa Ode Aswati ${ }^{2}$, Yulianti ${ }^{3}$ \\ Email: yuli19940705@gmail.com
}

\begin{abstract}
This study aims to evaluate the internal control system which is guided by government regulation number 60 of 2008 concerning the government's internal control system and are to investigate the factors which influence the realization of revenue on the land and building taxes in district kolaka. This research was conducted at the Tax Management Agency and Regional Retribution of the district kolaka. The data analysis method used in this research is descriptive analysis method. The type of data used in this study is qualitative, qualitative data in the form of questionnaires. The method of data collection uses questionnaire and interview methods.

The results of this study indicate that the percentage of the internal control system is categorized as adequate with a value of $80.19 \%$. The percentage obtained by each indicator, namely for the Control Indicator Environment is categorized as adequate with a value of 64,24\%. The Risk Assessment Indicator is categorized as adequate with a value of 66,56\%. The Indicator of Control Activities is categorized as very adequate with a value of 97,65\%. Information and Communication indicators are categorized as very adequate with a value of $81,24 \%$. Monitoring indicators are categorized as adequate with a value of 73,12\%. Overall, the five indicators show a adequate category, which is 80,19\%. The percentage of the local tax admissions system is categorized very according to the value of 100,00\%. The percentage obtained by each indicator, namely for the Registration \& Data Indicator is categorized as very suitable with a value of 100,00\%. Determination indicators \& objections are categorized as very suitable with a value of $100.00 \%$. Billing Indicators are categorized as very suitable with a value of $100.00 \%$. Overall, the three indicators show very suitable categories, namely $100,00 \%$. The lack of realization of land and building taxes in district kolaka is caused by several external factors, namely: (1) Lack of public awareness. (2) Taxpayers do not reside in the tax object. (3) Taxpayers ' home tenants or only while occupying tax objects. (4) Taxpayers are not recognised. (5) The Taxpayer name error in Notification of Tax Due (L\&B Tax). (6) The Tax object address does not match the actual condition.
\end{abstract}

Keywords: Internal Control System, Regional Tax Collection System.

\section{PENDAHULUAN}

Indonesia adalah negara besar yang mempunyai wilayah luas dan masyarakat beragam yang disatukan oleh Pancasila dan Undang-Undang Dasar 1945. Indonesia bercita-cita untuk melindungi segenap warga negara, memajukan kesejahteraan umum, mencerdaskan kehidupan bangsa dan ikut serta dalam melaksanakan ketertiban dunia. Untuk mencapai cita-cita tersebut, pemerintah Indonesia melaksanakan pembangunan di segala bidang dan berupaya untuk mewujudkan kemandirian dalam pembiayaan pembangunan tersebut. Untuk menciptakan pembangunan yang merata di seluruh wilayah Indonesia, maka Pemerintah Pusat memberlakukan otonomi daerah. Menurut Undang-Undang Nomor 32 Tahun 2004 tentang Pemerintahan Daerah, otonomi daerah adalah hak, wewenang, dan kewajiban daerah otonom untuk mengatur dan mengurus sendiri urusan pemerintahan dan kepentingan masyarakat setempat sesuai dengan peraturan perundang-undangan. Otonomi daerah menuntut Pemerintah 
Daerah untuk dapat membiayai kebutuhan rumah tangganya sendiri dalam rangka melaksanakan pembangunan yang merata, sehingga daerah harus dapat memaksimalkan potensi yang dimiliki untuk menambah penerimaan daerah. Penyelenggaraan otonomi daerah berdasarkan pada beberapa prinsip yaitu peran serta masyarakat, keadilan, demokrasi, akuntabilitas, dan memperhatikan potensi serta keanekaragaman daerah. Kemandirian yang dimaksud adalah memanfaatkan kemampuan dalam negeri melalui peningkatan penerimaan negara dari berbagai sektor dan tidak bergantung lagi pada pinjaman luar negeri.

Jenis pajak daerah yang dikelola oleh BPPRD adalah Pajak Bumi dan Bangunan sektor Perkotaan dan Pedesaan (PBB-P2). Besaran target dan realisasi penerimaan PBB-P2 di Kabupaten Kolaka dapat dilihat pada tabel berikut:

\section{Tabel 1. Target dan Realisasi Penerimaan PBB-P2 Kabupaten Kolaka Tahun 2016 sampai 2018}

\begin{tabular}{|c|c|c|c|c|}
\hline No. & Tahun & Target & Realisasi & $\begin{array}{c}\text { Persentase } \\
(\boldsymbol{\%})\end{array}$ \\
\hline 1 & 2016 & Rp. 3.197.327.805 & Rp. 2.566.001.187 & 80,255 \\
\hline 2 & 2017 & Rp. 3.230.446.820 & Rp. 2.654.659.626 & 82,18 \\
\hline 3 & 2018 & Rp. 3.350.414.451 & Rp. 2.870.508.633 & 85,69 \\
\hline
\end{tabular}

Sumber: Badan Pengelola Pajak dan Retribusi Daerah kabupaten Kolaka

Realisasi penerimaan PBB-P2 Kabupaten Kolaka mengalami flukstuasi dalam kurun waktu 5 tahun yakni dari 2016-2018. Dari tebel 1.1 diketahui bahwa jumlah realisasi penerimaan pajak PBB-P2 selalu lebih rendah dari target penerimaan setiap tahunya. Tahun 2016, target penerimaan sebesar Rp. 3.197.327.805 dan realisasi sebesar Rp. 2.566.001.187 dengan presentase 80,255\% sebesar Tahun 2017, target penerimaan sebesar Rp. 3.230.446.820 dan realisasi sebesar Rp. 2.654.659.626 dengan persentase sebesar 82,18\%. Tahun 2018, target penerimaan sebesar Rp. 3.350.414.451 dan realisasi sebesar Rp. 2.870.508.633 dengan persentase sebesar $85,69 \%$.

Rendahnya realisasi penerimaan PBB-P2 tersebut, disebabkan beberapa faktor, diantaranya pemungutan PBB-P2 terkendala terhadap Wajib Pajak yang kurang memiliki kesaadaran dalam membayar pajaknya, dan wajib pajak yang tidak berdomisili pada objek pajak.

Pemerintah Kabupaten Kolaka merupakan salah satu Pemerintah Daerah yang melaksanakan kewenangan pemerintahan pada provinsi, sesuai dengan peraturan perundangundangan yang berlaku dan juga dalam hal pembangunan yang berkaitan dengan tanah di Kabupaten Kolaka. Pemungutan pajak daerah yang ada di Pemerintah Kabupaten Kolaka diserahkan pada Badan Pengelola Pajak dan Retribusi Daerah Kabupaten Kolaka. Pajak yang dipungut oleh Badan Pengolahan Pajak dan Retribusi Daerah Kabupaten Kolaka di Kabupaten Kolaka berdasarkan Peraturan Daerah No. 2 Tahun 2011 tentang Pajak Daerah. Pelaksanaan, pengawasan dan pengendalian peraturan daerah tentang pajak daerah ini dilaksanakan oleh dinas yang ada di Kabupaten Kolaka dan dalam melaksanakan tugasnya dapat bekerja sama dengan instansi yang terkait.

Badan Pengelola Pajak dan Retribusi Daerah Kabupaten Kolaka harus memiliki struktur pengendalian intern yang terdiri dari kebijakan-kebijakan dan prosedur-prosedur yang telah ditetapkan untuk memberikan jaminan yang layak bahwa tujuan Badan Pengelola Pajak dan Retribusi Daerah akan dapat tercapai. Sistem pengendalian intern di Badan Pengelola Pajak dan Retribusi Daerah tersebut dinilai penting karena dengan adanya sistem pengendalian intern, maka setidaknya dapat menghindari terjadinya kerugian. Sistem Pengendalian Intern dalam pemungutan pajak daerah ini berperan penting sebagai sarana evaluasi terhadap sistem dan prosedur yang telah ada. Evaluasi tersebut digunakan untuk mengukur seberapa baik sistem yang 
telah dijalankan agar pemungutan Pajak daerah dapat mencapai target yang telah ditetapkan guna mengoptimalkan kegunaannya.

Pengendalian intern pada Pemerintah Pusat dan daerah berpedoman pada PP Nomor 60 Tahun 2008 tentang Sistem Pengendalian Intern Pemerintah. Sistem Pengendalian Intern sangat penting dalam menunjang perbaikan pengelolaan pemerintah daerah dan merupakan faktor pendukung untuk menciptakan pemerintah yang akuntabel dan transparan sebagai cerminan dari kinerja yang baik. Kualitas Laporan Keuangan Pemerintah Daerah yang buruk dan penyajian yang belum dapat diharapkan secara wajar,salah satunya bisa disebabkan oleh lemahnya Pengendalian Intern.

Untuk menciptakan sistem pengendalian intern yang baik, maka tiap-tiap fungsional dapat melaksanakan intern cek secara otomatis pada suatu bagian lainnya, yang akhirnya akan menghasilkan suatu sistem administrasi pemungutan pajak daerah yang tertib dalam meningkatkan pendapatan daerah. Sesuai dengan latar belakang diatas, maka peneliti tertarik untuk mengambil judul "Evaluasi Penerapan Sistem Pengendalian Intern Pemerintah dalam Meningkatkan Penerimaan Pajak Daerah pada Pengelola Pajak dan Retribusi Daerah Kabupaten Kolaka".

Berdasarkan latar belakang di atas, maka rumusan masalah dalam penelitian ini adalah: Apakah Sistem Pengendalian Intern Pemerintah pada Badan Pengelola Pajak dan Retribusi Daerah Kabupaten Kolaka telah memadai? Adapun tujuan dari penelitian ini adalah untuk mengetahui: Sistem Pengendalian Intern Pemerintah pada Badan Pengelola Pajak dan Retribusi Daerah Kabupaten Kolaka Apakah telah memadai.

\section{Kajian Teori}

\section{KAJIAN PUSTAKA}

a. Pengertian Pajak

Menurut UU No 16 tahun 2009 tentang ketentuan umum dan Tata Cara Perpajakan, Pajak adalah kontribusi wajib kepada negara yang terutang oleh orang pribadi atau badan yang bersifat memaksa berdasarkan undang-undang, dengan tidak mendapatkan imbalan secara langsung dan digunakan untuk keperluan negara bagi sebesarbesarnya kemakmuran rakyat (Waluyo, 2013).

\section{b. Fungsi Pajak}

Untuk menjalankan fungsinya, pemerintah membutuhkan sumber pendanaan atau modal. Salah satu sumber pendapatan tersebut diperoleh dari pungutan pajak. Selain sebagai sumber pendanaan, pungutan pajak juga dapat digunakan sebagai pengatur dalam melaksanakan kebijakan pemerintah. Menurut Mardiasmo (2011), ada dua fungsi pajak, yaitu: (1) Fungsi Budgetair, Pajak sebagai sumber dana bagi pemerintah untuk membiayai pengeluaran-pengeluarannya. (2) Fungsi Mengatur (Regulerend) Pajak sebagai alat untuk mengatur atau melaksanakan kebijaksanaan pemerintah dalam bidang sosial dan ekonomi. Contoh, pajak yang tinggi dikenakan terhadap minuman keras untuk mengurangi konsumsi minuman keras, pajak yang tinggi dikenakan terhadap barang-barang mewah untuk mengurangi gaya hidup konsumtif.

\section{c. Syarat Pemungutan Pajak}

Agar pemungutan pajak tidak menimbulkan hambatan, maka pemungutan pajak harus memenuhi syarat sebagai berikut (Mardiasmo,2011) : (1) Pemungutan pajak harus adil (Syarat Keadilan) Sesuai dengan tujuan hukum, yakni mencapai keadilan, undang-undang dan pelaksanaan pemungutan harus adil. Adil dalam perundangundangan diantaranya mengenakan pajak secara umum dan merata, serta disesuaikan dengan kemampuan masingmasing. Sedangkan adil dalam pelaksanaannya yakni dengan memberikan hak bagi Wajib Pajak untuk mengajukan keberatan, penundaan dalam pembayaran dan pengajuan banding kepada Majelis Pertimbangan Pajak. 
(2) Pemungutan pajak harus berdasarkan undang-undang (Syarat Yuridis) Di Indonesia, pajak diatur dalam UUD 1945 pasal 23 ayat 2. Hal ini memberikan jaminan hukum untuk menyatakan keadilan, baik negara maupun warganya. (3) Tidak mengganggu perekonomian (Syarat Ekonomis) Pemungutan tidak boleh mengganggu kelancaran kegiatan produksi maupun perdagangan, sehingga tidak menimbulkan kelesuan ekonomi masyarakat. (4) Pemungutan pajak harus efisien (Syarat Finansial) Sesuai fungsi budgetair, biaya pemungutan pajak harus bisa ditekan sehingga lebih rendah dari hasil pemungutannya. (5) Sistem pemungutan pajak harus sederhana Sistem pemungutan pajak yang sederhana akan memudahkan dan mendorong masyarakat dalam memenuhi kewajiban perpajakannya.

\section{d. Stelsel Pemungutan Pajak}

(Mardiasmo 2013) pemungutan pajak dapat dilakukan berdasarkan tiga stelsel yaitu: Stelsel nyata (Riel Stelsel), stelsel anggapan (Fictive Stelsel), stelsel campuran

\section{e. Sistem Pemungutan Pajak}

Sistem pemungutan pajak yaitu: (1) Official Assessment System adalah suatu sistem pemungutan yang memberi wewenang kepada pemerintah (fiskus) untuk menentukan besarnya pajak yang terhutang oleh Wajib Pajak. (2) Self Assessment System adalah suatu sistem pemungutan pajak yang memberi wewenang kepada Wajib Pajak untuk menentukan sendiri besarnya pajak yang terhutang. (3) With Holding System suatu sistem pemungutan pajak yang memberi wewenang kepada pihak ketiga (bukan fiskus dan bukan Wajib Pajak) yang bersangkutan untuk menentukan besarnya pajak yang terhutang oleh Wajib pajak.

\section{Pajak Daerah}

\section{a. Pajak Bumi dan Bangunan}

Menurut UU No 28 tahun 2009 adalah pajak atas bumi dan/atau bangunan yang dimiliki, dikuasai, dan/atau dimanfaatkan oleh orang pribadi atau badan, kecuali kawasan yang digunakan untuk kegiatan usaha perkebunan, perhutanan, dan pertambangan. Wajib Pajak PBB adalah orang pribadi atau badan yang memiliki hak atau memperoleh manfaat atas tanah, memiliki, menguasai, memperoleh manfaat atas bangunan. Subjek PBB adalah orang atau badan yang secara nyata mempunyai hak atas bumi, memperoleh manfaat atas bumi, memiliki, menguasai, memperoleh manfaat atas bangunan. Wajib pajak memiliki kewajiban membayar PBB yang terutang setiap tahunnya. PBB harus dilunasi paling lambat 6 (enam) bulan sejak tanggal diterimanya SPPT oleh WP. Surat Pemberitahuan Pajak Terutang (SPPT) merupakan surat yang digunakan oleh Dirjen pajak untuk memberitahukan besarnya pajak terutang kepada wajib pajak. Sedangkan surat yang digunakan oleh wajib pajak untuk melaporkan data objek pajaknya disebut Surat Pemberitahuan Objek Pajak (SPOP).

\section{Sistem Pengendalian Intern}

\section{a. Definisi Sistem Pengendalian Internal}

Mulyadi (2008:163) mendefinisikan sistem pengendalian intern meliputi struktur organisasi, metode, ukuran-ukuran yang dikoordinasikan untuk menjaga kekayaan organisasi, mengecek ketelitian dan keandalandata akuntansi, mendorong efesiensi dan mendorong dipatuhinya kebijakan manajemen untuk mencapai tujuan yang ingin dicapai. Romney \& Steinbart (2006:229) pengendalian intern (internal control) adalah rencana organisasi dan metode bisnis yang dipergunakan untuk menjaga asset, memberikan informasi yang akurat dan andal, mendorong dan memperbaiki efesiensi jalannya organisasi, serta mendorong kesesuaian dengan kebijakan yang telah ditetapkan. Jadi sistem pengendalian intern adalah suatu perencanaan yang meliputi struktur organisasi dan metodemetode yang dikoordinasikan untuk menjaga kekayaan organisasi.

Dari berbagai definisi di atas dapat disimpulkan bahwa sistem pengendalian intern merupakan suatu sistem yang terdiri dari berbagai unsur dan tidak terbatas pada metode yang dianut oleh suatu organisasi dan membantu dalam mencapai tujuan dari suatu organisasi. 


\section{b. Tujuan Sistem Pengendalian Intern}

Menurut Mulyadi (2014:163), tujuan sistem pengendalian intern adalah:

1. Menjaga kekayaan organisasi

2. Mengecek ketelitian dan keandalan data akuntansi

3. Mendorong efisiensi, dan Mendorong dipatuhinya kebijakan manajemen

\section{c. Unsur-Unsur Sistem Pengendalian Intern Pemerintah}

Peraturan Pemerintah Republik Indonesia Nomor 60 Tahun 2008 tentang sistem pengendalian intern pemerintah, mengemukakan unsurunsur sistem pengendalian intern sebagai berikut:

1) Lingkungan pengendalian menempatkan kualitas dalam organisasi dan berperan untuk mempengaruhi kesadaran akan orang-orang yang terlibat dalam suatu instansi mengenai pentingnya pengendalian, sehingga dalam konsep ini menempatkan unsur lingkungan pengendalian sebagai pondasi dasar atau penentu irama bagi semua unsur dalam sistem pengendalian intern lainnya. Yang dimaksud lingkungan pengendalian adalah kondisi yang tercipta dalam suatu unit kerja/satuan kerja yang mempengaruhi efektivitas pengendalian intern.

2) Penilaian Risiko, tidak hanya pimpinan yang bertanggung jawab atas penilaian risiko yang akan dihadapi oleh suatu organisasi atau instansi pemerintah, melainkan seluruh pegawai yang ada di dalamnya harus mampu mengidentifikasi, mengevaluasi, dan memantau kejadian-kejadian yang akan menghambat pencapaian visi dan misi organisasi.

3) Risiko yang timbul dalam suatu organisasi dapat disebabkan karena adanya faktor internal dan eksternal. Kegiatan pengendalian adalah tindakan aktif sebagai suatu bentuk reaksi atas hasil penilaian risiko yang telah dilakukan sehingga mampu mengurangi risiko yang ada. Kegiatan pengendalian ini mencakup kebijakan maupun prosedur yang ditetapkan oleh pimpinan sehingga membantu memberikan keyakinan yang memadai bahwa tujuan instansi pemerintah telah tercapai. Kebijakan yang di buat diharapkan mampu mengarahkan tindakan apa saja yang seharusnya dilakukan dan berfungsi sebagai dasar untuk penyusunan prosedur. Prosedur yang dimaksud merupakan petunjuk atas rangkaian urut-urutan tindakan dalam melaksanakan kegiatan yang ada, yang disesuaiakan sesuai dengan ukuran, kompleksitas dan sifat dari tugas dan fungsi instansi pemerintah.

4) Informasi dan Komunikasi, Informasi merupakan hasil dari data yang telah diolah yang akan digunakan sebagai media pengambilan keputusan, sedangkan komunikasi adalah proses penyampaian informasi kepada pihak lain baik secara langsung maupun tidak langsung dan mendapat umpan balik. Informasi dan komunikasi yang berkualitas dan efektif dapat mempengaruhi kemampuan pimpinan untuk membuat keputusan yang tepat dan membantu pegawai untuk mampu memahami tugas dan tanggungjawabnya sehingga pada akhirnya mampu memperkuat efektivitas sistem pengendalian intern itu sendiri.

5) Pemantauan, Aktivitas pemantauan menurut COSO merupakan kegiatan evaluasi dengan beberapa bentuk apakah yang sifatnya berkelanjutan, terpisah maupun kombinasi keduanya yang digunakan untuk memastikan apakah masing-masing dari kelima komponen pengendalian internal mempengaruhi fungsi- fungsi dalam setiap komponen, ada dan berfungsi. Evaluasi berkesinambungan, (terus menerus) dibangun ke dalam proses bisnis pada tingkat yang berbeda dari entitas menyajikanyajikan informasi yang tepat waktu. Evaluasi terpisah dilakukan secara periodik, akan bervariasi dalam lingkup dan frekuensi tergantung pada penilaian risiko, efektifitas evaluasi yang sedang berlangsung, bahan pertimbangan manajemen lainnya. Temuan-temuan dievaluasi terhadap kriteria yang ditetapkan oleh pembuat kebijakan, lembaga- lembaga pembuat standar yang diakui atau manajemen dan dewan direksi, dan kekurangan kekurangan yang ditemukan dikomunikasikan kepada manajemen dan dewan direksi. Kegiatan pemantauan meliputi proses penilaian kualitas kinerja pengendalian internal sepanjang waktu, dan memastikan apakah semuanya dijalankan seperti yang diinginkan serta apakah telah disesuaikan dengan 
perubahan keadaan. Pemantauan seharusnya dilakukan oleh personal yang semestinya melakukan pekerjaan tersebut, baik pada tahap desain maupun pengoperasian pengendalian pada waktu yang tepat, guna menentukan apakah pengendalian internal beroperasi sebagaimana yang diharapkan dan untuk menentukan apakah pengendalian internal tersebut telah disesuaikan dengan perubahan keadaan yang selalu dinamis. Secara singkat dapat dikatakan bahwa pemantauan dilakukan untuk memberikan keyakinan apakah pengendalian internal telah dilakukan secara memadai atau tidak. Dari hasil pemantauan tersebut dapat ditemukan kelemahan dan kekurangan pengendalian sehingga dapat diusulkan pengendalian yang lebih baik.

Adapun ukuran presentase yang digunakan untuk melihat Apakah sistem pengendalian internal pemerintah telah memadai berdasarkan PP RI Nomor 60 tahun 2008 adalah sebagai berikut :
a) Angka 0\%-20\%= Sangat lemah / Sangat tidak memadai
b) Angka $21 \%-40 \%=$ Lemah / Tidak memadai
c) Angka $41 \%-60 \%=$ Cukup / Cukup memadai
d) Angka $61 \%-80 \%=$ Kuat $/$ memadai
e) Angka $81 \%-100 \%=$ Sangat kuat $/$ Sangat memadai

\section{METODE PENELITIAN}

Objek dalam penelitian ini adalah Evaluasi Penerapan Sistem Pengendalian Intern dalam Meningkatkan Penerimaan Pajak Daerah pada Pengelola Pajak dan Retribusi Daerah Kabupaten Kolaka. populasi dalam penelitian ini yaitu seluruh karyawan yang bekerja di Badan Pengelola Pajak dan Retribusi Daerah Yang berjumlah 103 orang. Sampel pada penelitian ini ditentukan dengan cara purposive sampling, yaitu bentuk penarikan sampel dengan menggunakan kriteriakriteria tertentu. Adapun kriteria yang digunakan adalah:

1. Pegawai yang memantau dan melasanakan Pengendalian Internal pada Badan Pengelola Pajak dan Retribusi daerah Kota Kendari.

2. Pegawai yang berhubungan dengan Pemungutan Pajak Bumi \& Bangunan Pedesaan dan perkotaan pada Badan Pengelola Pajak dan Retribusi daerah Kota Kendari.

Berikut uraian mengenai sampel yang akan digunakan:

Tabel. 3.1. Populasi dan Sampel

\begin{tabular}{|c|l|c|}
\hline No. & \multicolumn{1}{|c|}{ Jabatan } & Jumlah Orang \\
\hline 1. & Kepala Badan Pengelola Pajak Dan Retribusi Daerah Kabupaten Kolaka & 1 \\
\hline 2. & $\begin{array}{l}\text { Sekretaris Badan Pengelola Pajak Dan Retribusi Daerah Kabupaten } \\
\text { Kolaka }\end{array}$ & 1 \\
\hline 3. & Kepala bidang Pengelolaan PBB-P2 dan BPHTB & 1 \\
\hline 4. & Subid. Pendataan dan Penilaian PBB-P2 & 1 \\
\hline 5. & Staf Pendataan dan Penilaian PBB-P2 & 2 \\
\hline 6. & Subid. Pengolahan Data dan Informasi PBB-P2 dan BPHTB & 1 \\
\hline 7. & Staf Pengolahan Data dan Informasi PBB-P2 dan BPHTB & 1 \\
\hline 8. & Subid. Penagihan, Keberatan dan Banding PBB-P2 DAN BPHTB & 3 \\
\hline 9. & Staf Penagihan, Keberatan dan Banding PBB-P2 DAN BPHTB & 12 \\
\hline 10. & Kepala UPTB PBB-P2 Kecamatan & 12 \\
\hline 11. & Staf UPTB PBB-P2 Kecamatan & $\mathbf{3 7 ~ O r a n g}$ \\
\hline
\end{tabular}

Jenis data yang digunakan dalam penelitian ini, yaitu data data Kualitatif. Data Kualitatif menggambarkan tentang kondisi penerimaan pajak daerah di Badan Pengelola Pajak dan Retribusi Daerah Kabupaten Kolaka. Data tersebut berupa pertanyaan-pertanyaan tentang sistem pengendalian intern penerimaan pajak daerah (Kuesioner) dan dokumen-dokumen pendukung dalam penelitian. 
Sumber data yang digunakan dalam penelitian ini adalah Data primer. Menurut Indrianti \& Bambang (2009:146) adalah data yang diperoleh secara langsung dari sumber asli. Data primer dalam penelitian ini berupa jawaban atas kuisioner yang dibagikan kepada responden.

Metode pengumpulan data dalam penelitian ini yaitu kuesioner dan wawancara. Kuesioner yaitu teknik pengumpulan data dengan mengajukan daftar pertanyaan yang kepada responden terkait dengan permasalahan yang diteliti dengan tujuan untuk mendapatkan tanggapan dari responden. Pertanyaan dalam kuesioner dalam penelitian ini diukur dengan menggunakan skala Guttman dengan pilihan jawaban yang diberikan terdiri dari jawaban "ya" dan "tidak". Wawancara, adalah percakapan dengan maksud tertentu. Percakapan itu dilakukan oleh dua pihak, yaitu pewawancara yang mengajukan pertanyaan dan yang terwawancara yang memberikan jawaban atas pertanyaan itu. Dalam penelitian ini pihak yang diwawancarai yaitu staf bagian pemungutan pajak daerah dan Sekretaris di Badan Pengelola Pajak Dan Retribusi Daerah Kabupaten Kolaka.

Metode analisis yang digunakan dalam pemecahan masalah yang dibahas adalah metode analisis deskriftif, yaitu memaparkan tentang penerapan sistem pengendalian intern dalam meningkatkan penerimaan pajak daerah di kantor BPPRD Kabupaten Kolaka. Untuk mengukur tingkat efektifitas penerapan sistem pengendalian intern, peneliti menggunakan pendekatan kuisioner dengan memberikan dua alternatif jawaban menggunakan skala Guttman dengan penelitian sebagai berikut:

$\begin{array}{ll}\text { Jawaban Ya } & =1 \\ \text { Jawaban Tidak } & =0\end{array}$

Persentase jawaban responden terhadap efektifitas penerapan sistem pengendalian intern dalam meningkatkan penerimaan pajak daerah di kantor BPPRD Kabupaten Kolaka sebagai berikut:

Keterangan:

$$
p=\frac{f}{n} \times 100 \%
$$

$\mathrm{P}=$ Persentase

$\mathrm{F}=$ Jumlah jawaban responden

$\mathrm{N}=$ total skor jawaban tertinggi

Sumber : Riduwan (2008:28)

Kriteria pengukuran dari hasil perhitungan persentase kesesuaian indikator dengan penggolongan sebagai berikut:

Angka 0\%-20\% = Sangat Lemah / Sangat Tidak Memadai

Angka $21 \%-40 \%=$ Lemah $/$ Tidak Memadai

Angka $41 \%-60 \%=$ Cukup $/$ Cukup Memadai

Angka $61 \%-80 \%=$ Kuat $/$ Memadai

Angka $81 \%-100 \%=$ Sangat Kuat $/$ Sangat Memadai

Sumber : Riduwan (2008:28)

\section{Hasil Penelitian}

\section{HASIL PENELITIAN DAN PEMBAHASAN}

a. Sistem Pengendalian Internal Pemerintah

Tabel 4.9 Perhitungan Persentase Sistem Pengendalian Intern pada Badan Pengelola Pajak dan Retribusi Daerah Kabupaten Kolaka Berdasarkan Hasil Jawaban Kuesioner

\begin{tabular}{|l|c|c|c|c|}
\hline & $\begin{array}{c}\text { Jawaban } \\
\text { "YA" }\end{array}$ & $\begin{array}{c}\text { Jawaban } \\
\text { "TIDAK" }\end{array}$ & $\begin{array}{c}\text { Presentase } \\
(\boldsymbol{\%})\end{array}$ & $\begin{array}{c}\text { Jumlah } \\
\text { Jawaban }\end{array}$ \\
\hline Lingkungan Pengendalian & 538 & 262 & 64.24 & 800 \\
\hline Penilaian Resiko & 213 & 18 & 66,56 & 231 \\
\hline
\end{tabular}




\begin{tabular}{|l|c|c|c|c|}
\hline & $\begin{array}{c}\text { Jawaban } \\
\text { "YA" }\end{array}$ & $\begin{array}{c}\text { Jawaban } \\
\text { "TIDAK" }\end{array}$ & $\begin{array}{c}\text { Presentase } \\
(\mathbf{\% )}\end{array}$ & $\begin{array}{c}\text { Jumlah } \\
\text { Jawaban }\end{array}$ \\
\hline Kegiatan Pengendalian & 375 & 9 & 97,65 & 384 \\
\hline Informasi dan Komunikasi & 182 & 42 & 81,24 & 224 \\
\hline Pemantauan & 263 & 57 & 73,12 & 320 \\
\hline Total & 1.571 & 388 & 80,19 & 1.959 \\
\hline
\end{tabular}

$$
\text { Persentase }=\frac{1.571}{1.959} x 100 \%=80,19(\text { Memadai })
$$

Tabel 4.10 diatas menunjukkan bahwa persentase Sistem Pengendalian Intern pada Badan pengelola pajak dan Retribusi Daerah Kabupaten Kolaka adalah sebesar 80,19 \% atau dapat dikatakan Sistem Pengendalian Internal pada Badan pengelola pajak dan Retribusi Daerah Kabupaten Kolaka sudah memadai.

b. Sistem Pemungutan Pajak Bumi \& Bangunan

Tabel 4.11 Perhitungan Persentase Sistem Penerimaan Pajak PBB-P2 pada Badan Pengelola Pajak dan Retribusi Daerah Kabupaten Kolaka Berdasarkan Hasil Jawaban Kuesioner

\begin{tabular}{|l|c|c|c|c|}
\hline & $\begin{array}{c}\text { Jawaban } \\
\text { "YA" }\end{array}$ & $\begin{array}{c}\text { Jawaban } \\
\text { "TIDAK" }\end{array}$ & $\begin{array}{c}\text { Presentase } \\
(\boldsymbol{\%})\end{array}$ & $\begin{array}{c}\text { Jumlah } \\
\text { Jawaban }\end{array}$ \\
\hline $\begin{array}{l}\text { Pendaftaran \& } \\
\text { Pendataan }\end{array}$ & 576 & 0 & 100.00 & 576 \\
\hline Penetapan \& keberatan & 288 & 0 & 100.00 & 288 \\
\hline Penagihan & 64 & 0 & 100.00 & 64 \\
\hline Total & 928 & 0 & 100.00 & 928 \\
\hline
\end{tabular}

$$
\text { Persentase }=\frac{928}{928} x 100 \%=100.00(\text { Sangat Memadai })
$$

Tabel 4.12 diatas menunjukkan bahwa persentase Sistem Penerimaan pajak Daerah pada Badan pengelola pajak dan Retribusi Daerah Kabupaten Kolaka adalah sebesar 100\% atau dapat dikatakan Sistem Penerimaan pajak Daerah pada Badan pengelola pajak dan Retribusi Daerah Kabupaten Kolaka sudah sangat memadai.

\section{Pembahasan}

(1) Evaluasi Sistem Pengendalian Intern Penerimaan Pajak Daerah Pada Badan Pengelola Pajak Dan Retribusi Daerah Kabupaten Kolaka

\section{a. Sistem Pengendalian Internal Pemerintah}

Pelaksanaan Sistem Pengendalian Intern pada Badan Pengelola Pajak dan Retribusi daerah Kabupaten Kolaka dapat dilihat berdasarkan unsur-unsur pengendalian intern sesuai yang tercantum dalam PP RI Nomor 60 Tahun 2008. Untuk memperkuat dan menunjang efektivitas penyelenggaraan Sistem Pengendalian Intern dilakukan pengawasan intern dan pembinaan penyelenggaraan pengendalian internal di sektor publik bertujuan untuk mencapai pengelolaan keuangan publik yang efektif, efisien, transparan, dan akuntabel (pasal 2 PP No 60 Tahun 2008) Keberadaan sistem pengendalian intern sangat penting bagi suatu institusi karena Pengendalian yang lemah akan mengakibatkan kerugian, skandal, kegagalan, bahkan kebangkrutan atau rusaknya reputasi Jika risiko dibiarkan saja tanpa adanya media pengendali risiko, maka hal tersebut akan menjadi permasalahan institusi dalam mencapai tujuannya (Pickett, 2009:86) Berdasarkan lima komponen pengendalian internal Sistem Pengendalian Internal Pemerintah (PP No 60 tahun 2008), terkait Badan Pengelola Pajak dan Retribusi daerah Kabupaten Kolaka dapat dijelaskan sebagai berikut: 


\section{Lingkungan Pengendalian}

Lingkungan Pengendalian yang diterapkan di Badan Pengelola Pajak dan Retribusi Daerah Kabupaten Kolaka sebagai berikut:

Penegakan nilai integritas dan etika, Adanya visi, misi, dan tujuan Badan Pengelola Pajak dan Retribusi Daerah Kabupaten Kolaka sehingga kepala dinas, kepala bidang serta karyawan berusaha menciptakan lingkungan kerja yang nyaman dan bekerja sama dalam mencapai suatu tujuan organisasi. Nilai etika pengawai yang diterapkan di Badan Pengelola Pajak dan Retribusi Daerah Kota Kendari salah satunya adalah kedisiplinan. Yaitu pengawai diharapkan datang tepat waktu dan pulang sesuai dengan waktu yang sudah ditentukan. Komitmen Terhadap Kompetensi, Komitmen terhadap kompetensi yang dilakukan oleh Badan Pengelola Pajak dan Retribusi Daerah Kabupaten Kolaka ialah pengangkatan tiap pegawai pada jabatan tertentu masih belum berdasarkan kemampuan dan keahlian. Untuk itu diharapkan Badan Pengelola Pajak dan Retribusi Daerah Kabupaten Kolaka dalam penerimaan pengawai dilakukan secara objektif dan selektif. Karena masih dilihatnya kendala yang berhubungan sumber daya manusia. Penyusunan dan penerapan kebijakan yang sehat tentang pembinaan sumber daya manusia, Adanya pemberian pelatihan khusus bagi pengawai seperti adanya diklat pemagangan sesuai dengan perubahan regulasi dari pusat, maupun pengembangan kinerja bagi pengawai yaitu dengan kedisiplinan dan melihat tanggung jawab dari masing-masing pengawai untuk meningkatkan kinerja.

Namun dibidang tertentu belum diberlakukan penghargaan terhadap pengawai yang kinerjanya dinilai baik. Kepemimpinan yang kondusif, Adapun Kepala Dinas memberikan instruksi mengenai pelaksanaan pekerjaan, selain itu figur kepala dinas dalam berpilaku memberikan contoh kepada seluruh bawahannya yaitu melalui interaksi secara intensif sehingga komunikasi antar bawahan akan tetap terjaga. Kepimpinan yang kondusif dapat dipahami dengan memperhatikan visi dan misi Badan Pengelola Pajak dan Retribusi Daerah Kabupaten Kolaka. Pembentukan struktur organisasi sesuai dengan kebutuhan, Dalam Menjalankan fungsinya tersebut Badan Pengelola Pajak dan Retribusi Daerah Kabupaten Kolaka menyusun pendelegasikan wewenang dan tanggung jawab yang terstruktur dalam struktur organisasi yang berdasarkan pada fungsi.

Pendelegasian Wewenang dan Tanggung jawab, Badan Pengelola Pajak dan Retribusi Daerah Kabupaten Kolaka telah memberikan wewenang kepada pegawai yang tepat sesuai dengan tingkat tanggung jawabnya. Struktur organisasi Badan Pengelola Pajak dan Retribusi Daerah Kabupaten Kolaka berpedoman pada Peraturan Daerah. Badan Pengelola Pajak dan Retribusi Daerah Kabupaten Kolaka mempunyai struktur organisasi garis dan staff yaitu wewenang dan tugas berasal dari pimpinan dan dibantu oleh masing-masing bagian.

2. Penilaian Risiko

Penaksiran risiko yang diterapkan di Badan Pengelola Pajak dan Retribusi Daerah Kabupaten Kolaka yaitu mengidentifikasi permasalahan berdasarkan pada tugas dan fungsi Satuan Kerja Perangkat Daerah (SKPD). Untuk menganalisa risiko yang dihadapi manajemen, Badan Pengelola Pajak dan Retribusi Daerah Kota kendari menggunakan metode penilaian risiko yang sesuai untuk tujuan instasi pemerintah. Berdasarkan penjelasan diatas Badan Pengelola Pajak dan Retribusi Daerah Kabupaten Kolaka, telah melaksanakan penaksiran risiko dengan baik hal ini dilihat adanya rencana dan strategi serta kebijakan yang ditetapkan untuk mengidentifikasi risiko tersebut.

3. Kegiatan Pengendalian

Badan Pengelola Pajak dan Retribusi Daerah Kabupaten Kolaka telah melaksanakan kegiatan pengendalian secara efektif, karena dalam kegiatan pengendalian Badan Pengelola Pajak dan Retribusi Daerah Kabupaten Kolaka setiap kejadian-kejadian dan transaksi-transaksi disertai otorisasi oleh pihak yang berwenang agar tidak terjadinya penyimpangan atau kebocoran dari pajak daerah, adanya pemisahan tugas yang menjadi acuan dalam melaksanakan tugas, 
tanggung jawab, dokumen dan catatan yang memadai yang sudah bernomor urut cetak. Sehingga hal ini mendukung jalannya sistem dan prosedur pemungutan pajak daerah yang memadai.

4. Informasi dan Komunikasi

Sistem Informasi dan komunikasi yang diterapkan oleh Badan Pengelola Pajak dan Retribusi Daerah Kabupaten Kolaka telah terkomputerisasi. Yaitu dengan adanya sistem pengelolaan keuangan berbasis teknologi berupa Sistem Informasi Manajemen Daerah (SIMDA). SIMDA adalah sistem yang dapat menunjang kinerja yang berhubungan dengan pendapatan daerah dan dapat melihat sampai sejauh mana pendapatan daerah tercapai. Dari sistem ini digunakan untuk mendapat informasi wajib pajak yang sudah membayar pajak maupun yang belum melunasi pajak terutangnya. Melalui sistem ini lebih mudah mendapatkan informasi untuk melakukan rangkaian penerimaan pajak. Dalam hal ini, Badan Pengelola Pajak dan Retribusi Daerah Kabupaten Kolaka telah menerapkan sistem Informasi dan komunikasi yang baik dan memadai.

5. Pemantauan

Bagi Badan Pengelola Pajak dan Retribusi Daerah Kabupaten Kolaka pemantauan dilakukan untuk mengoptimalkan penerimaan daerah. pemantauan dilaksanakan oleh petugas pengawasan khusus pada seksi pendataan, pendaftaran, penetapan dan penagihan bidang pendapatan daerah, petugas tersebut diberikan tanggung jawab dalam bentuk melakukan Waskat (Pengawasan Melekat) dimana pengawai ditunjuk langsung untuk memantau pelaku-pelaku usaha dalam membayar pajak, dengan tujuan untuk meningkatkan pendapatan daerah dan juga pengendalian internal pajak daerah sangat diperhatikan oleh pihak Badan Pengelola Pajak dan Retribusi Daerah Kabupaten Kolaka agar supaya mengoptimalkan penerimaan daerah. Ada juga penegasan yang diberikan agar tidak terjadinya pelanggaran yang dilakukan wajib pajak. Adanya audit eksternal yaitu BPK (Badan Pemeriksa Keuangan) selaku pihak yang berkewajiban melakukan pengawasan dan pemeriksaan untuk memantau perkembangan Badan Pengelola Pajak dan Retribusi Daerah Kabupaten Kolaka serta memastikan pelaksanaan aktivitas setiap bagian terutama penerimaan pajak dilaksanakan sesuai dengan sistem dan prosedur yang berlaku. Dalam hal ini Badan Pengelola Pajak dan Retribusi Daerah Kabupaten Kolaka telah melaksanakan pemantauan dengan baik.

\section{b. Sistem Penerimaan Pajak Bumi dan Bangunan}

1. Bidang Pendaftaran dan pendataan

Sub Bidang Pendaftaran dan Pendataan mempunyai tugas menyiapkan bahan pelaksanaan pendaftaran pajak daerah dan menyiapkan bahan pelaksanaan pendataan pajak daerah.

Fungsi Sub Bidang Pendaftaran, sebagai berikut :

1) Penyusunan rencana kerja Subbidang Pendaftaran.

2) Perumusan kebijakan teknis pendaftaran pajak daerah.

3) Pelaksanaan pendaftaran calon wajib pajak daerah.

4) Evaluasi dan penyusunan laporan pelaksanaan kerja Subbidang Pendaftaran

Fungsi Sub Bidang Pendataan, sebagai berikut :

1) Penyusunan rencana kerja Subbidang Pendataan.

2) Perumusan kebijakan teknis pendataan pajak daerah.

3) Pelaksanaan pendataan subyek dan objek pajak daerah.

4) Pelaksanaan administrasi benda berhaga.

5) Evaluasi dan penyusunan laporan pelaksanaan kerja Subbidang Pendataan.

2. Bidang Penetapan dan Keberatan

Bidang penetapan dan keberatan mempunyai tugas membantu Menyiapkan bahan pelaksanaan dan pembinaan penetapan pajak. Fungsi Sub Bidang Penetapan, sebagai berikut :

1) Penyusunan rencana kerja Subbidang Penetapan.

2) Perumusan kebijakan teknis penetapan pajak daerah. 
3) Pelaksanaan analisis pajak daerah.

4) Pelaksanaan penetapan dan penerbitan surat ketetapan pajak daerah.

5) Evaluasi dan penyusunan laporan pelaksanaan kerja Subbidang Penetapan.

Persyaratan yang harus dipenuhi dalam mengajukan permohonan keberatan, sebagai berikut:

a. Permohonan keberatan wajib dilampiri dengan:

1) Fotokopi bukti penerimaan jaminan dari Bea dan Cukai sebesar tagihan yang harus dibayar atau bukti pelunasan tagihan dalam hal tagihan yang timbul akibat penetapan telah dilunasi

2) Fotokopi SPTNP, SPP, SPSA atau penetapan lainnya oleh Pejabat Bea dan Cukai; dan

3) Data dan/atau bukti pendukung pengajuan keberatan.

b. Keberatan diajukan secara tertulis dengan ketentuan:

1) Keberatan diajukan dalam jangka waktu paling lama 60 (enam puluh) hari sejak tanggal surat penetapan. Pemohon hanya dapat mengajukan 1 (satu) permohonan keberatan secara tertulis untuk setiap penetapan Pejabat Bea dan Cukai.

2) Pemohon hanya berhak atas 1 (satu) kali kesempatan untuk mengajukan permohonan keberatan secara tertulis.

3) Apabila keberatan tidak diajukan sampai dengan jangka waktu 60 (enam puluh) hari sejak tanggal surat penetapan, hak untuk mengajukan keberatan menjadi gugur dan penetapan Pejabat Bea dan Cukai dianggap diterima

4) Dalam hal hari ke-60 (enam puluh) bertepatan dengan bukan hari kerja, pengajuan keberatan dapat dilakukan pada hari kerja berikutnya

5) Atas jaminan yang diserahkan, Pejabat Bea dan Cukai melakukan konfirmasi jaminan kepada penerbit jaminan.

6) Dalam hal pengajuan keberatan dengan menyerahkan jaminan, persetujuan pengeluaran barang diberikan setelah terdapat hasil konfirmasi jaminan yang menyatukan jaminan tersebut benar.

3. Bidang Penagihan

Bidang Penagihan mempunyai tugas membantu Kepala Dinas dalam memimpin, mengendalikan, dan mengkoordinasikan penyelenggaraan urusan pemerintahan dan pelayanan umum yang menjadi kewenangan Dinas pada bidang yang meliputi perencanaan pendapatan, intensifikasi dan ekstensifikasi serta pelaporan pembukuan. Dalam melaksanakan tugas pokok bidang penagihan menyelenggarakan fungsi:

1) Penyusunan rencana, program dan kegiatan bidang penagihan.

2) Penyusunan petunjuk teknisa lingkup pembukuan, verifikasi, penagihan, perhitungan, pertimbangan dan restitusi.

3) Pelaksanaan pembukuan dan verifikasi atas pajak daerah, retribusi daerah dan pendapatan daerah lainnya.

4) Pelaksanaan penagihan atas tunggakan pajak daerah, retribusi daerah dan pendapatan daerah lainnya.

5) Pelaksanaan perhitungan restituri dan pemindahan bukuan atas pajak daerah, retribusi daerah dan pendapatan daerah lainnya.

6) Pelaksanaan telaahan dan saran pertimbangan terhadap keberatan wajib pajak atas permohonan wajib pajak.

7) Pelaksanaan monitoring, evaluasi dan pelaporan lingkup bidang penagihan.

8) Pelaksanaan tugas lainnya yang diberikan oleh kepala dinas sesuai dengan tugas dan fungsinya. 
Berdasarkah hasil penelitian yang telah dilakukan, ditemukan bahwa rendahnya realisasi penerimaan PBB-P2 di kabupaten Kolaka tidak sesuai dengan target penerimaan PBB-P2 yang ditargetkan BPPRD kabupaten Kolaka, hal ini disebabkan beberapa kendala diantaranya:

1. Kurangnya kesadaran masyarakat.

Dalam pemungutan pajak dituntut kesadaran warga negara untuk memenuhi kewajiban kenegaraan. Kurangnya atau tidak adanya kesadaran masyarakat sebagai wajib pajak untuk membayar pajak ke bpprd mengakibatkan timbulnya perlawanan atau terhadap pajak yang merupakan kendala dalam pemungutan pajak sehingga mengakibatkan berkurangnya penerimaan pajak yang tidak memenuhi target.

2. Wajib Pajak tidak berdomisili pada Objek Pajak.

Pemilik Objek Pajak bertempat tinggal diluar kota, sedangkan tidak ada nomor yang bisa dihubungi oleh ketua RT. Terkadang ketua RT sudah tidak mengetahui siapa pemilik atas objek tersebut

3. Wajib Pajak Penyewa Rumah atau hanya sementara menempati Objek Pajak.

Beberapa Wajib Pajak yang menyewa tidak mau menerima SPPT dengan alasan tidak bertemu dengan pemilik rumah

4. Wajib Pajak tidak dikenal.

Wajib Pajak tidak dikenal karena saat pendataan Wajib Pajak hanya bersifat mengontrak dan tidak adanya pendataan ulang dari DPPKA

5. Kesalahan nama Wajib Pajak pada SPPT.

Kesalahan nama Wajib Pajak pada SPPT terjadi seperti adanya dobel huruf, salah ketik huruf vocal, misalnya seharusnya Purwanto tetapi tertera Purwanta Wajib Pajak tidak mau menerima. Kesalahan nama juga ketika ada nama baptis tidak tertera pada SPPT Wajib Pajak tidak mau menerima

6. Alamat Objek Pajak tidak sesuai dengan kondisi sebenarnya.

Kesalahan yang tertera pada SPPT juga terjadi karena adanya kesalahan alamat Objek Pajak dengan kondisi sebenarnya. Wajib Pajak tidak mau menerima SPPT karena merasa tidak memiliki Objek Pajak pada alamat tersebut.

\section{KESIMPULAN DAN SARAN}

Berdasarkan hasil dan pembahasan serta uraian pada bab-bab sebelumnya, maka

Kesimpulan dari penelitian ini adalah :

1. Sistem Pengendalian Intern yang dilaksanakan oleh Badan Pengelola Pajak dan Retribusi Daerah Kabupaten Kolaka telah memadai sesuai dengan Peraturan Pemerintah RI No. 60 Tahun 2008 Tentang Sistem Pengendalian Intern Pemerintah.

2. Sistem penerimaan pajak bumi \& bangunan yang dilaksanakan oleh Badan Pengelola Pajak dan Retribusi Daerah Kabupaten Kolaka sudah sangat memdai.

3. Rendahnya realisasi penerimaan PBB-P2 di Kabupaten Kolaka disebabakan oleh beberapa faktor eksternal yaitu: (1) kurangnya kesadaran masyarakat. (2) wajib pajak tidak berdomisili pada objek pajak. (3) wajib pajak penyewa rumah atau hanya sementara menempati objek pajak. (4) wajib pajak tidak dikenal. (5) kesalahan nama wajib pajak pada SPPT. (6) alamat objek pajak tidak sesuai dengan kondisi sebenarnya.

Adapun Saran yang diberikan dalam penelitian ini adalah :

1. Sistem dan prosedur penerimaan pajak daerah pada Badan Pengelola Pajak dan Retribusi Daerah Kabupaten Kolaka sudah berjalan dengan baik, disarankan untuk lebih ditingkatkan lagi dalam mengembangkan sistem dan prosedur penerimaan pajak sehingga dapat berjalan sesuai dengan prosedur.

2. Badan Pengelola Pajak dan Retribusi Daerah Kabupaten Kolaka diharapkan dapat lebih mempertahankan Sistem Pengendalian Intern yang sudah baik. 
3. Bagi Peneliti selanjutnya disarankan untuk menambahkan teori-teori yang ada dan melakukan pengembangan terhadap kuesioner dan wawancara pada pihak-pihak yang bersangkutan dengan variabel yang diteliti agar hasilnya lebih baik lagi atau bisa dengan mengembangkan teori yang lebih luas misalnya dengan judul "Faktor-Faktor Penyebab Tidak Tercapainya Target Pajak Bumi Dan Bangunan Di Kabupaten Kolaka".

\section{DAFTAR PUSTAKA}

Bodnar \& Hopwood. 2006. Sistem Informasi Akuntansi, Buku I. Jakarta: Salemba Empat. Indrianto, Nur dan Supomo, Bambang : 2002. Metodelogi Penelitian Bisnis. BPFE, Yogyakarta Mardiasmo. 2013. Perpajakan Edisi Revisi, Andi Offset, Yogyakarta

Mulyadi. 2008. Sistem Akuntansi. Jakarta: Salemba Empat. . 20014. Sistem Akuntansi. Jakarta: Salemba Empat.

Nasution, S. 2003. Metode Research (Penelitian Ilmiah). Jakarta: BumiAksara.

Peraturan Pemerintah Republik Indonesia Nomor 60 Tahun 2008 mengenai Sistem Pengendalian Intern Pemerintah (SPIP).

Riduwan. 2008. Metode dan Teknik Menyusun Proposal Penelitian. Alfabeta : Bandung.

Riduwan. 2013. Dasar-Dasar Statistika. Bandung: Alfabeta.

Romney \& Steinbart.2006. Accounting Information System. Jakarta: Salemba Empat.

Sidik, Machfud, 2002, Optimalisasi Pajak Daerah dan Retribusi Daerah dalam Rangka Meningkatkan Kemampuan Keuangan Daerah, Orasi Ilmiah Disampaikan pada Acara Wisuda XXI STIA LAN, Bandung, 10 April 2002.

Sugiyono, 2016, Metode Penelitian Pendidikan (Pendekatan Kuantitatif Kualitatif, dan $R \&$ D). Bandung: Alfabeta

Sugiyono. 2012. Metode Penelitian Kuantitatif Kualitatif dan R\&D. Bandung: Alfabeta.

Tandaju, Ivana Peggie dan Inggriani Elim. 2015. Evaluasi Penerapan Pengendalian Intern Siklus Penerimaan Kas pada Dinas Pendapatan, Pengelolaan Keuangan dan Aset Daerah Kabuapten Kepulauan Sanghie. Universitas Sam Ratulangi Manado. ISSN 23031174.

Undang-Undang Nomor 28 Tahun 2009 tentang Pajak Daerah dan Retribusi Daerah.

Undang-Undang Nomor 16 Tahun 2009 Tentang Ketentuan Umum Dan Tata Cara Perpajakan.Jakarta.

Waluyo. 2013. Perpajakan Indonesia. Graha Ilmu. Yogyakarta.

Wa Ode Mustika Ratu. 2019. Evaluasi Sistem Pengendalian Internal Pemungutan Pajak Daerah pada Badan Pengelola Pajak dan Retribusi Daerah Kota Kendari. Skripsi. Universitas Halu Oleo. Kendari.

Venna Maria Aroran, Jantje Tinangon, Novi S. Budiarso. 2016. Evaluasi Penerapan Sistem Pengendalian Penerimaan Kas (Studi Kasus pada Dinas Pendapatan Daerah Kota Manado. Universitas Sam Ratulangi Manado. Jurnal Berkala Ilmiah Efisiensi Vol. 6 No. 03 Tahun 2016.

Virdalen dan Titik Mildawati. 2016. Evaluasi Pengendalian Internal Pajak Daerah Dinas Pendapatan dan Pengelolaan Keuangan Surabaya. Jurnal Ilmu dan Riset Akuntansi: Vol. 5 No. 12, Desember 2016. 